ICMB21

\title{
The monitoring of wall moisture in a property retrofitted with Internal Wall Insulation
}

\author{
Tim Martel ${ }^{1}$, Eric Rirsch ${ }^{2}$, Andrew Simmonds ${ }^{3}$ and Clementine Walker ${ }^{4}$ \\ Association for Environment Conscious Building, UK; timmartel3@gmail.com \\ Safeguard Europe Ltd, Horsham, UK; eric.rirsch@safeguardeurope.com \\ Association for Environment Conscious Building, UK; ceo@aecb.net \\ 4 Safeguard Europe Ltd, Horsham, UK; clementine.walker@safeguardeurope.com \\ * Correspondence: eric.rirsch@safeguardeurope.com ; Tel. : +44-1403-210204
}

\begin{abstract}
The purpose of this study was to measure the long-term moisture build-up in the walls of a house which had been retrofitted with Internal Wall Insulation. This was done by embedding moisture sensors in the walls and then monitoring values over an eight-year period. The results showed that the wall moisture of embedded wood piece sensors had increased to a value of $18-20 \%$ over 8 years. In a comparable wall, which had been treated with a masonry water repellent in the form of a cream, the build-up of moisture was significantly reduced to $9-10 \%$ over the same period. This wall was examined after the 8 -year period and no visible mould was evident on the internal face of the wall, behind the insulation.
\end{abstract}

Peer-review under the responsibility of the organizing committee of the ICMB21.

Keywords: moisture; insulation; monitoring, water repellent, hygrothermal

\section{Nomenclature}

\section{Introduction}

The current objective of UK energy policy is to reach zero emissions by 2050 from all use in buildings. At the moment $41 \%$ of UK CO2 emissions result from building use with an annual fuel spend of $£ 13 \mathrm{bn}$. [1]. In order to reach this target, widespread retrofitting to reduce energy consumption and peak demand on the future decarbonised grid is required. The adoption of insulation to reduce heating demand is key to reaching the target. Measures need to be 'moisture robust' for both newly applied materials and the original materials incorporated into the assembly. Improving rain resistance of the external faces of walls with internal wall insulation (IWI) could be a robust way to improve performance and longevity of the building assembly. Poorly designed, specified or installed insulation can lead to problems with moisture build-up within building assemblies.

Hygrothermal modelling has shown that the application of IWI has been found to increase the moisture content of the exterior wall [2][3]. In the current project, IWI was incorporated into a house retrofit and the effect of this on wall moisture was measured over an 8-year period. The aim of the study was to measure the moisture build-up in the wall and see if a water repellent masonry cream cream applied to the outside of the wall had an influence on this.

\section{Materials and Methods}

\subsection{Property and Insulation}

A 19th century brick and stone solid-wall house in rural Herefordshire was used for the case study. The house was substantially retrofitted, with different types of insulation used in the walls, floor and roof. The project required the original appearance of the west facing front wall of the house to be retained and therefore internal wall insulation was used on this aspect. The IWI was an open cell polyurethane spray foam with a thermal conductivity of $0.037 \mathrm{~W} / \mathrm{mK}$, density of $18 \mathrm{~kg} / \mathrm{m}^{3}$ and $\mu$-value of 3.3 to EN 12086. The foam was applied to give a total thickness of $150 \mathrm{~mm}$. The U-value was calculated to be $0.23 \mathrm{~W} / \mathrm{m}^{2} \mathrm{~K}$. The property was in a moderate exposure zone for wind driven rain (33 to $<56.51 / \mathrm{m}^{2}$ per spell).

\subsection{Waterproofing brick cream}

A waterproofing masonry cream was used to impart water repellency to the external face of the brickwork. The product is a water-based cream emulsion formulated from silane and siloxane components. Waterproofing is achieved without significant loss of moisture vapour permeability which allows a damp wall to dry [4]. Testing has shown that treatment causes a reduction 


\section{ICMB21}

of $\sim 97 \%$ in the water absorption coefficient (A-value) of the brick and reduces the water vapour permeability by less than $10 \%$. The left-hand half of the front face of the property was treated with the brick cream by applying with a roller and brush. The right-hand half of the property was left untreated and used as an experimental control. The results shown in Figure 1 show that drying of the wall was not inhibited by the brick cream treatment. Before deciding on the suitability of brick cream for the property the wall was treated to prevent rising damp as a precaution, and salts were not deemed to be an issue.

\subsection{Data Loggers and locations}

The GE-Protimeter HygroTrac system was used. This is a wireless sensor system which uploads the information to a website where temperature, humidity and wood moisture content are recorded. The sensors are calibrated for spruce and are battery powered with a life of 10-years plus. The technical specification of the HygroTrac sensor is given in Table 1. The sensors were mounted on small wood pieces $(100 \mathrm{~mm}$ x $50 \mathrm{~mm}$ x $25 \mathrm{~mm}$ ) all cut from the same piece of spruce softwood.. The sensor and wood assemblies were placed in different locations in the property, sensors were embedded in the brickwork of the living room and dining room walls at a height of $0.4 \mathrm{~m}$. Temperature, moisture content (WME), and relative humidity were recorded once per hour over the 8 year period.

Table 1: Technical Specifications of Sensor (from GE Measurement, 2014)

\begin{tabular}{|c|c|c|}
\hline Property & Range & Accuracy \\
\hline Moisture Content & $8 \%$ to $40 \%$ & $+/-1 \%$ \\
\hline RH & $0 \%$ to $100 \%$ & $+/-2.5 \%$ in the $0-90 \%$ range \\
\hline Temperature & -40 to $85{ }^{\circ} \mathrm{C}$ & $+/-0.5{ }^{\circ} \mathrm{C}$ \\
\hline
\end{tabular}

\section{Results}

\subsection{Moisture Changes}

The figure below shows how the moisture content of the timber pieces with attached sensors embedded in the brick wall changed over the course of the eight years of testing. Figure 1 shows that for the sensor on the internal face of the Living Room wall (brick cream treated), that the moisture content initially started at approximately $25 \%$ and declined over a period of 6 months to $10 \%$, with this remaining somewhat steady over the following 7 years. In the Dining Room (where the outer wall was untreated) there was initially a decline but then a gradual increase again over a period of 7 years to $18-20 \%$ moisture content, likely due to rewetting of the wall from rain penetration. The initial high moisture content in both walls is likely due to the moisture introduced when carrying out the renovation works. The moisture content of both walls decreased as drying occurred over the first year, with the brick cream treated wall showing a faster drying time and reaching a lower moisture content than the untreated wall.

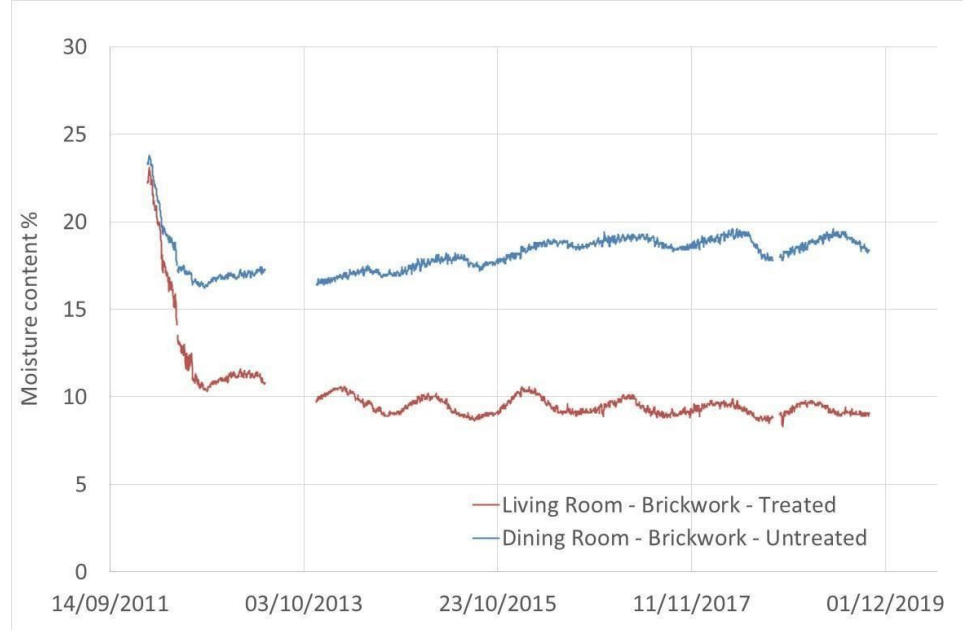

Figure 1. Variation in the moisture content of the wood pieces sensors embedded in brickwork (downstairs rooms)

\section{References}

[1] Boardman, B (2019) Achieving zero: delivering future-friendly buildings, In Proceedings of AECB Conference, Oxford, UK, June 2019

[2] Kunzl, H. M. Effect of interior and exterior insulation on the hygrothermal behaviour of exposed walls. Materials and Structures/Materiaux et Constructions 1998, 31, 99-103.

[3] Cascione, V.; Marrab, E.; Zirkelbach, D.; Liuzzia, S.; Stefanizzi, P. Hygrothermal analysis of technical solutions for insulating the opaque building envelope. Energy Procedia 2017, 126, 203-210

[4] BBA - British Board of Agrément Certificate No.15/5198 2015 